\title{
Diontos
}

Revista de Comunicación Digital

\section{La focalización mediática en los principales informativos de televisión en España en las campañas electorales generales de 2019: partidos políticos versus líderes}

\section{Media targeting in Spain's main TV news programmes in the $\mathbf{2 0 1 9}$ general election campaigns: political parties versus leaders}

\author{
Benjamín Marín Pérez \\ benjamin.marin@uv.es \\ Universitat de València
}

\author{
Javier Pérez-Sánchez \\ javier.perez@universidadeuropea.es \\ Universidad Europea de Madrid
}

\begin{abstract}
Anastasia loana Pop anastasia.pop@uv.es Universitat de València
\end{abstract}

\section{Resumen}

Este artículo se refiere a la presencia en televisión de los principales partidos y líderes políticos candidatos a la Presidencia del Gobierno español durante las elecciones generales del 28 de abril de 2019 y del 10 de noviembre del mismo año. El objetivo del estudio es comparar el protagonismo que las cadenas dan en la información electoral a los partidos políticos y a los líderes, y comprobar las diferencias por cadena y según cada proceso electoral. Para ello se ha hecho un estudio cuantitativo y cualitativo sobre las menciones que los líderes y los partidos tuvieron en los informativos de prime time de las tres cadenas de TDT de más audiencia de España en los dos procesos electorales de 2019, del 12 al 29 de abril y del 1 al 11 de noviembre. Las menciones a los líderes y partidos están registradas bajo el análisis del contenido con la voz en off de las noticias y en directo de los periodistas y en base a la rotulación que acompaña las noticias y a las imágenes que se utilizan en las piezas. Del estudio se concluye que Antena 3, Tele 5 y TVE dan mayor protagonismo en televisión a los líderes que a los partidos políticos. También se extrae de la investigación que hay mayor protagonismo de los líderes políticos cuando la campaña es más corta y que Tele 5 y Antena 3 expresan la referencialidad al cargo de líder en sus noticias a diferencia de TVE, donde ésta es residual.

\section{Palabras clave}

partidos políticos; líderes políticos; informativos televisivos; campañas; elecciones generales 2019

Este artículo forma parte del proyecto financiado por el Ministerio de Economía y Competitividad español "Estrategias, agendas y discursos en las cibercampañas electorales: medios de comunicación y ciudadanos" (2017-2020). Referencia CSO2016-77331-C2-1-R. 


\begin{abstract}
This article focuses on the television coverage of the main political parties and leaders who are candidates for the Presidency of the Spanish Government during the general elections of April 28, 2019 and November 10 of the same year. The purpose of the research is to compare the protagonist main role that the television gives to political parties and leaders in electoral news, to verify the differences by news programmes, and according to each electoral process. This study is based on the quantitative and content analysis of the mentions the leaders and parties had in the prime time news of the three television channels with the highest audience in Spain during the two electoral processes of 2019, from April 12 to 29 and November 1 to 11 . The mentions of the leaders and parties are registered under the content analysis with the voiceover of the news and live recordings of the journalists based on the captions and the images that accompany the news. The study concluded that television news from Antena 3, Tele 5 and TVE gives more visibility to the leaders than to the political parties. Also, research shows that political leaders have an increased visible presence when the campaign is shorter. Also, research shows that political leaders have an increased visible presence when the campaign is shorter, and that Tele 5 and Antena 3 reference the leader's position in their news, as opposed to TVE, where it is minimal.
\end{abstract}

\title{
Keywords
}

political parties; political leaders; TV news; campaigns; 2019 General Elections

La focalización mediática en los principales informativos de televisión en España en las campañas electorales generales de 2019: partidos políticos versus líderes

\section{Introducción}

En las últimas décadas, la comunicación política ha sido una de las disciplinas que más ha evolucionado tanto en la forma como en el contenido. Sin duda, el principal cambio ha sido la mediatización de la política: el creciente papel de los medios de comunicación en la vida política (Donofrio y Rubio, 2019). Los medios de comunicación y la política se han necesitado mutuamente a lo largo de la historia para ejercer ambos su función capital. Los mass media han transformado la vida política y los candidatos contemporáneos los necesitan porque el electorado observa a través de ellos las informaciones y propuestas de sus dirigentes (Berrocal, 2003).

El año 2019 fue un año electoral intenso en España con elecciones municipales y autonómicas en varias comunidades, las europeas y dos elecciones generales celebradas el 28 de abril y el 10 de noviembre. Esta última precedida por la campaña electoral más corta de la democracia con tan solo 8 días de duración, siendo el periodo habitual de campaña electoral de 15 días. Esta circunstancia electoral sin un precedente proporciona una innovación y un estudio único sobre la labor realizada por los principales informativos televisivos en las dos campañas electorales, dado que la reducción del tiempo habitual de la campaña es inherente a que se produzcan modificaciones en la propia cobertura mediática de estos eventos políticos.

El principal agente que ha transformado el camino de los políticos es la televisión 
(Berrocal, 2003). En los últimos años, la importancia de la televisión en la comunicación política ha experimentado cambios merced al influjo de las redes sociales, que canalizan buena parte del discurso político, tanto el que elaboran los partidos políticos como el difundido por los ciudadanos (López-García, 2016; Campos, Valera, López García, 2015). En ese sentido, las plataformas digitales están cambiando la información política, pero no están sustituyendo al periodismo y los medios convencionales (Casero-Ripollés, 2018).

Esto produce un nuevo entorno híbrido en el que las dos lógicas, la vinculada a los medios digitales, por un lado, y la asociada al sistema mediático tradicional, por otro, conviven a veces armónicamente, generando cooperaciones y sinergias, y en otras ocasiones colisionan, provocando conflictos y tensiones (Chadwick, 2017). En todo caso, ambas se superponen y se interrelacionan constantemente (Casero-Ripollés, 2018).

Respecto a los medios tradicionales, en las campañas electorales la televisión es el medio preferido por los espectadores para seguir la información política y el de mayor influencia entre los electores (Peris y López-Rico, 2017; Schulz, Zeh y Quiring, 2005). De hecho, a pesar del peso creciente de las redes sociales, la televisión sigue siendo más importante que internet para la captación de votos en periodo electoral (SanjuánPérez, Martínez-Costa y Nozal-Cantarero, 2019).

Durante los períodos electorales, gran parte de los informativos televisivos buscan transmitir mensajes políticos, cuya finalidad es informar al público elector sobre las propuestas de campaña y transferir al público la importancia que dan a los diferentes temas (Crespo, 2002). Para Van Aelst, Sheafer y Stanyer (2012) el foco de la cobertura de noticias se ha desplazado desde los partidos y organizaciones a los candidatos y dirigentes.

A pesar de ello, el contenido informativo ofrecido por la televisión proporciona a la audiencia una imagen controlada de los políticos y la familiariza con la actividad política, además de acercar la figura de los candidatos, personificando la imagen de los partidos, asemejándose a la tradición norteamericana de marketing político (De la Paz Vila Márquez, 2016).

Para Donofrio y Rubio (2019) a la par de la mediatización de la política se generan dos fenómenos adicionales: por un lado, el protagonismo creciente de la imagen, hasta el punto que algunos autores hablan de la audiovisualización de la política. La imagen prevalece sobre el contenido: no es tan importante lo que se dice, sino cómo se dice; los políticos cuidan su imagen, controlan su lenguaje corporal, los asesores se encargan del llamado making-off de los candidatos, la importancia de la puesta en escena; y el protagonismo es de la televisión, sin duda el medio masivo preferido por los políticos, ya que representa "el único lugar y el único momento" en el que un candidato se pone en contacto simultáneo con "todos los electores", más allá de que éstos estén a favor o en contra de su postulación e independientemente de sus perfiles socio-demográficos (Cayrol, 1997: 525).

\section{Personalización de la política en los medios}

Por ello es crucial el nuevo papel que los medios de comunicación y especialmente la televisión han otorgado a la personalización de la política (Keeter, 1987; Brants y Voltmer, 2011). Esta tendencia ocupa cada vez más interés y provoca más investigaciones. Una 
personalización de la política que trata del protagonismo que cada vez más tienen los líderes en relación con las fuerzas políticas a las que representan y su traslación en impactos a los medios de comunicación.

La personalización desde el sistema de los medios se ha investigado principalmente en el ámbito de la comunicación. Muchas investigaciones se centran en la cobertura mediática sobre el contexto político, destacando la cobertura en prensa como principal muestra de análisis (Rahat y Sheafer, 2007; Langer, 2011; Reinemann y Wilke, 2007; Holtz-Bacha, Langer y Merkle 2014; Porath, León-Porath, Ramdohr y Suzuki, 2015; Rebolledo, Rodríguez-Virgili y Jandura, 2016). También hay algunos estudios relativos a la cobertura en el medio televisivo (Rospir, 1999; Bucy y Grabe, 2007; Schulz y Zeh, 2005; Laguna, 2003 y 2011; Scammel y Semetko, 2008; Rodríguez, Jandura y Rebolledo, 2014; Pasquino, 2016; Rebolledo, 2017, Donofrio y Rubio (2019).

En opinión de Rodríguez, Janduray Rebolledo (2014), se puede estudiar la personalización de la política desde tres perspectivas: la del sistema político, la de los medios y la del comportamiento del electorado.

La historia muestra que la personalización constituye un elemento inherente a la vida política. Sin embargo, la aparición de los medios de comunicación, especialmente los audiovisuales, provoca un salto cualitativo en el predominio de la imagen, y con ello, de la persona frente a ideas, conceptos u organizaciones colectivas (Rebolledo, 2017).

Por lo que respecta a la personalización de la política en las redes sociales, éstas permiten conectar emocionalmente con los usuarios y generar autenticidad en torno a un líder político para que éste sea percibido como alguien confiable, genuino y cercano (Enli, 2015). A este objetivo se orienta gran parte de la producción de contenidos operada por los políticos (Casero-Ripollés, 2018). Más que ofrecer información por sí misma, la finalidad principal reside en la autopromoción. El empleo de Instagram es revelador en este sentido (Selva-Ruiz, Caro-Castaño, 2017).

Dentro del ecosistema de las redes sociales, Twitter tiene un peso muy notable en la construcción de los liderazgos políticos (Harris y Rae, 2011) ya que permite acercarse al público, construir una imagen controlada y reforzar lazos con la comunidad de seguidores. Se consolida como herramienta clave en el desarrollo de las campañas políticas (Campos-Domínguez y Calvo, 2017), convirtiéndose en la red social más usada para visibilizar la figura del líder político.

La personalización de la política conlleva implícito el concepto del liderazgo del candidato. Es esencial distinguir entre los partidos políticos y los líderes que los representan. Para algunos autores, a menudo se habla de los líderes como si sus personas representasen toda la política de sus paísesy/o del partido que encabezan. En ese sentido para Pasquino (2016:19) "resulta equivocado pensar que la notoriedad y la visibilidad signifiquen de por sí personalización de la política. Ambos aspectos son fenómenos que contribuyen a la personalización, pero por sí solos constituyen solamente sus premisas, a menudo efímeras y no destinadas a durar".

Sin embargo, para Rospir (1999) la atención individualizada sobre los principales líderes y candidatos que las cámaras realizan dio paso a este fenómeno de la personalización de la política. Y la televisión amplifica este efecto. El líder dejaría de ser una pieza más de esa trilogía en que se basa el sistema competitivo electoral (junto al programa 
y al partido), para convertirse en la guía electoral más destacada... de igual manera que los electores voten antes por el político que por las políticas la suerte de las elecciones recaería de forma especial en el candidato (Laguna, 2011:46-47).

Para Laguna (2003) con el reinado de la televisión en el mundo de la comunicación social, la centralidad del líder frente a la organización es un hecho, no sólo por la adecuación al estilo hiperpersonalista que impuso la estrategia sensacionalista del mercado, sino por el principio de simplificación que establece el lenguaje audiovisual.

El líder aparece ante millones de hogares en la pequeña pantalla para informar o proporcionar significados a la información queya ha sido difundida (Del Rey, 1989). Para Martín Salgado (2002) la llegada de la televisión lo cambió todo. Mediante este medio de comunicación el líder puede acceder a las casas de los ciudadanos sin necesidad de recurrir a la mediación de militantes $u$ otra estructura del partido, pudiendo ofrecer así aspectos familiares de su personalidad. Y de esta forma, las campañas electorales empezaron a pivotar sobre el líder de forma rápida.

En esta línea, Manin (1997:219) asegura que "los votantes tienden cada vez más a votar por una persona y no tanto por un partido o plataforma". Las características que se quieran destacar del político se enmarcan dentro de una estrategia definida y orientada para alcanzar un objetivo determinado. Éste, a su vez, se materializa mediante decisiones y acciones políticas, pero también a través de la imagen del propio candidato (Rebolledo, 2017).

En las dos campañas generales de 2019 en España que analizamos en este trabajo, hemos podido observar cómo los líderes protagonizaron actos con motoristas yendo vestidos como ellos (Albert Rivera) o asistían a una procesión de Semana Santa con el traje de nazareno (Pablo Casado). Se trata de un concepto de liderazgo político basado en la visibilidad del medio; un liderazgo creado y diseñado para "ser observado" como símbolo de acciones y propuestas de su partido o de su gobierno (Rospir, 1999). Un liderazgo "electrónico", en la medida en que su existencia, continuidad o futuro pende del medio audiovisual. Por eso, "el líder electrónico no tiene un pueblo; tiene público, tiene espectadores" (Colombo, 1976:120).

Se destacan los atributos del candidato y se resta importancia a las ideologías como elemento diferenciador entre partidos, lo que reduce la política a un enfrentamiento entre personalidades (Sánchez-Murillo, 2005). Es la personalización del influencer político, que actúa en la mayoría de los casos desconectado de la ideología (Rahat; Sheafer, 2007; López-Meri; Marcos-García; Casero-Ripollés, 2017), que aplica técnicas de comunicación y marketing y que ha encontrado en las redes sociales un abono eficaz para despertar la atención de comunidades activas de fans o detractores (PérezCuriel y García-Gordillo, 2018).

Por su parte, las televisiones en su afán por ganar audiencia incrementan este fenómeno y por ello no es fácil encontrar una noticia política sin que haya referencia al líder de ese partido. Pero, ¿hasta qué punto? Los líderes cada vez tienen más protagonismo respecto a su propio partido. De hecho, en la actualidad el político a nivel individual parece ser un elemento vertebrador de las decisiones políticas que toman los electores (Wattenberg, 1998; Rico, 2009; Garzia, 2014).

Son los medios de comunicación quienes condicionan el voto y la batalla política se 
libra dentro de sus parámetros. Al mismo tiempo, los medios de comunicación están encargados de distraer a los ciudadanos, construyendo una realidad ficticia, donde la democracia termina por identificarse con el televoto (Donofrio y Rubio, 2019).

El medio televisión aborda la cobertura mediática de unas elecciones bajo el prisma de cada cadena: línea ideológica, si es de carácter pública o privada y el público al cual se dirige. La Junta Electoral Central establece a los medios los tiempos de intervención de los partidos políticos en base a la representación parlamentaria que obtuvieron en las pasadas elecciones. Esta premisa se lleva prácticamente a rajatabla en las televisiones públicas, pero no en las privadas donde prima más la audiencia, el interés informativo y la espectacularización de la información. De hecho, TVE no aceptó en la campaña de las elecciones de abril un debate a cinco con el líder de Vox, Santiago Abascal, porque no tenía representación parlamentaria, pero Atresmedia sí lo incluyó en el suyo porque era una fuerza emergente de gran atractivo para su audiencia.

La cobertura mediática de una campaña electoral por parte de cada cadena también se establece en función de los recursos económicos y humanos que dedican a esa contienda. A nivel de contenido y estructura de la escaleta de cada informativo, cada medio de comunicación organiza la información en base a los parámetros que considera establecidos en su libro de estilo. Por ejemplo, las 3 cadenas, pero especialmente TVE, utilizaron con mucha asiduidad piezas informativas combinadas donde podían incluir mención a 5 o 6 partidos distintos. Piezas de 2 minutos de duración o por el contrario algunas de apenas 12 o 20 segundos. El recurso del directo lo utilizan las 3 cadenas analizadas porque le da fuerza a la información de las televisiones inmersas en la caravana electoral por todo el territorio nacional.

Después cada cadena tiene sus recursos estéticos a la hora de ejecutar la edición de la información. TVE solo utiliza rotulación fuera de totales cuando es directo o falso directo del periodista mientras que tanto Tele 5 como Antena 3 sí la utilizan, especialmente cuando se trata de piezas combinadas donde se hace mención expresa a varios partidos y líderes.

Esta y otras cuestiones relativas a la construcción de las noticias son fundamentales para esta investigación. De hecho, los parámetros para determinar el mayor o menor protagonismo de los líderes y los partidos se establecen mediante el análisis de las noticias bajo los criterios de análisis del contenido con la voz en off y en directo de los periodistas, la rotulación que acompaña las noticias y las imágenes que se utilizan en las piezas.

El corpus del trabajo se basa en el estudio sobre las menciones que los líderes y los partidos tuvieron en los informativos de prime time de las tres cadenas de TDT de más audiencia de España en los dos procesos electorales de 2019, del 12 al 29 de abril y del 1 al 11 de noviembre.

En España, desde las elecciones generales de 2015 hasta las celebradas en 2019, la televisión sigue siendo la principal pantalla audiovisual, si bien existen cambios importantes. Según el Centro de Investigaciones Sociológicas, el 56\% de las personas eligieron la ventana de la televisión como primera fuente de información política en la última campaña electoral de 2019 (CIS, 2019).

Los cambios políticos es lo que más ha influido en el intercambio de espectadores 
entre los distintos informativos de los canales generalistas. Desde 2012 se produjo un trasvase de espectadores de La1 (TVE) a Telecinco principalmente, situando a esta última como primera opción informativa en el año 2015 (Barlovento Comunicación, 2016). Durante 2016, el Telediario de La1 recuperó el liderazgo de sobremesa y se convertía en la principal alternativa a Telecinco (Barlovento Comunicación, 2017).

El reflejo de la influencia política en la línea editorial, y su relación con la audiencia, se observa claramente en 2018, cuando se produce la primera moción de censura que prospera en democracia y un posterior cambio de Gobierno en España. Entonces la audiencia de los informativos cambia completamente: Antena 3 Noticias pasa a liderar los informativos del mediodía e Informativos Telecinco sigue siendo la opción de la noche, pero en sumatorio Antena 3 se pone líder de cuota de pantalla con 14 puntos de share de media (Barlovento Comunicación, 2019).

Sin embargo, donde más evidente es la evolución y el reparto de espectadores es en el año electoral de 2019. Los espacios informativos de Telecinco y Antena 3 prácticamente empatan en cuota de pantalla (14,5 y 14,6 de share respectivamente).

\section{Objetivos, metodología e hipótesis}

La importancia de la investigación que se propone parte del tratamiento que los medios de comunicación, y en concreto la televisión, hacen del protagonismo de los líderes políticos, contribuyendo de forma manifiesta a la personalización de la política, al espectáculo, y a la mediatización de la comunicación política, reforzando la idea de que este medio muestra al electorado un escaparate de personalidades para que elija su voto. Un medio que para muchos autores es el más decisivo para cautivar al electorado en su elección.

Por ello, la investigación se centra en el papel del medio televisión y deja de lado la perspectiva del partido y del electorado. Este estudio tiene como objetivos responder a las siguientes preguntas: ¿Cómo personaliza la televisión la campaña electoral? ¿Cómo reduce la televisión la política a la figura del líder? ¿Cómo articula el protagonismo informativo al candidato? ¿Bajo qué parámetros lo hace? ¿Cómo contribuye a la simplificación de la política a través de la construcción del relato a través de los candidatos? ¿Dónde incide más la televisión: en los partidos o en sus líderes? ¿Qué recursos utiliza?

De esta manera, se plantea como uno de los principales objetivos el establecer las diferencias en cuanto al tratamiento que las tres cadenas de más audiencia de España (Telecinco, Antena 3 y Televisión Española) hicieron respecto a los líderes y los partidos políticos en las dos campañas electorales de 2019. La investigación analiza qué hizo cada cadena en cada campaña y establece una comparativa para ver la diferencia del protagonismo que otorgó al líder y al partido político que lo sustenta. La importancia dada a los distintos partidos políticos en los tres informativos más relevantes del ámbito nacional son una parte importante de la investigación.

Otro objetivo es hacer una comparación del protagonismo de los líderes políticos respecto a los partidos políticos en las dos campañas electorales. El estudio pretende analizar el peso de los candidatos en las distintas piezas informativas frente a sus respectivos partidos. 
El diseño metodológico en este estudio está basado en dos muestras temporales correspondientes a las dos campañas electorales generales del 2019. Se han seleccionado y analizado las piezas informativas de las campañas electorales a las Cortes Generales de los tres espacios informativos con mayor audiencia en la edición de la noche. De todas las noticias seleccionadas se ha reducido la muestra a las que estén relacionadas con los cinco partidos más votados en ambas campañas, que comprenden al Partido Socialista Obrero Español (PSOE), Partido Popular (PP), Vox, Unidas Podemos (UP) y Ciudadanos (Cs). La primera selección de análisis corresponde al periodo comprendido entre el 12 y el 29 de abril, ambos inclusive, y la segunda del 1 al 11 de noviembre. El intervalo de tiempo estudiado está comprendido por la campaña electoral, la jornada de reflexión, la votación y el día posterior de las dos campañas electorales. Estos dos periodos suponen un total de 266 unidades de análisis, y más de 278 minutos analizados, divididas en 107 piezas son del Telediario 2 de RTVE que corresponden al 40,22\% del total; de Antena 3 Noticias 2 son 84 piezas, que suponen el 31,58\%; y por último las 75 piezas de Informativos Telecinco, que ocupan el 28,56\%.

Las 266 piezas seleccionadas pertenecen a un estudio más amplio con 709 noticias de índole política de los informativos analizados durante ambas campañas. En este artículo se ha centrado concretamente en los cinco partidos políticos nombrados anteriormente, profundizando en el análisis sobre el protagonismo y el peso del líder político sobre el partido, la referencialidad visual, sonora y gráfica de las piezas, y el reparto de piezas entre los distintos partidos y las propias campañas. Para la realización de esta investigación se ha llevado a cabo una ficha de análisis de cada noticia que nos ha permitido desglosar la importancia del partido político, del líder o candidato, así como las referencia a los rivales electorales dentro de las propias piezas informativas. En este tipo de análisis se descomponen las piezas en unidades de codificación, que son los elementos de estudio que se cuantifican en cada una de las categorías y dimensiones de protagonismo en cuanto a imagen audiovisual, rótulos o locución, distinguiendo los siguientes valores: líder político, partido político, otros líderes o candidatos, otros políticos $u$ otras personas.

Para afrontar el objeto de estudio en toda su dimensión y complejidad, el análisis realizado no sólo cuantifica las veces que aparecen estos codificadores y de qué manera (imagen, rótulo, off), sino que además tiene en consideración variables objetivas en cuanto al modo de presentación de la información y los propios totales emitidos de los líderes políticos. En este sentido se ha prestado especial atención a las formas discursivas y estilos narrativos, sobre todo a la hora de estudiar los liderazgos y la personalización de la política en las piezas de los informativos. Por ejemplo, se ha atendido a variables en el corpus del mensaje y de los totales en la referencialidad al cargo del líder político, al análisis de la referencialidad del líder político en los totales bien a sí mismo, a su partido, a otros líderes u a otros partidos, asignando una serie de pesos y ponderaciones que permiten esclarecer y ofrecer unos resultados claros sobre las menciones otorgadas a los partidos y a los líderes de cada formación en las dos campañas de 2019.

Como se ha mencionado ya, los contenidos elegidos para este análisis son: Informativos Telecinco, Antena 3 Noticias y el Telediario de La1 (TVE) de las ediciones de prime time. Estos programas informativos son los más vistos, y poseen el mayor intercambio de espectadores entre los distintos canales asociado a los diferentes eventos políticos y 
electorales, tema principal en esta investigación. En el estudio además se ha distribuido las piezas por partidos e informativos, así como la distinción de la muestra temporal de la campaña, en el caso del estudio.

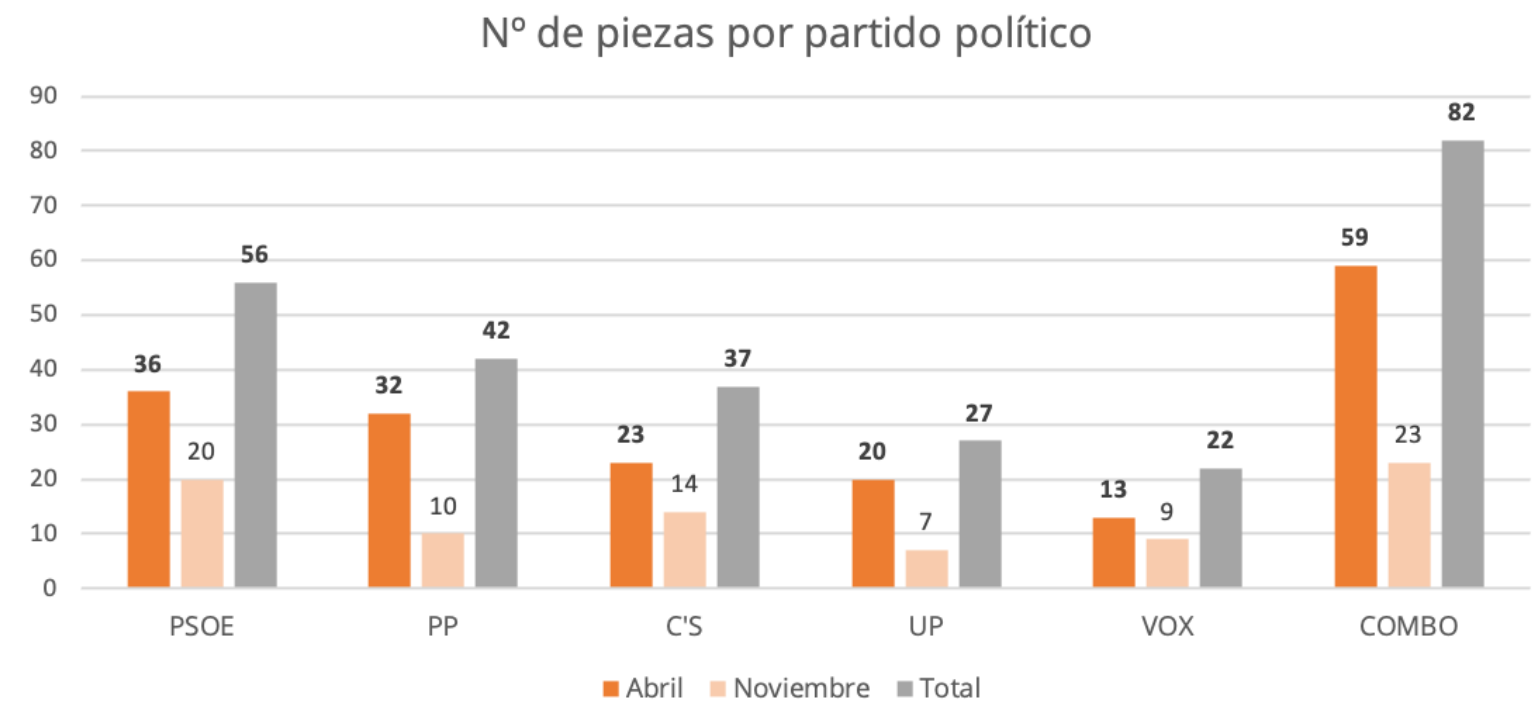

Gráfico 1. Número de piezas analizadas por partido y campaña electoral de 2019. Realización propia.

En resumen, esta investigación es un estudio cuantitativo principalmente, pero también cualitativo que analiza el contenido del mensaje, en ambos casos mide y analiza la relevancia de los líderes y los partidos políticos en los tres informativos de los medios de comunicación más vistos en España en 2019. Por lo que el objetivo de este estudio no es evaluar la credibilidad de los mensajes políticos ni los temas tratados por ellos, sino cuantificar y explorar la presencia de los líderes y de los partidos políticos en estos tres espacios informativos durante las dos campañas electorales nacionales de 2019, y la personalización de la política en los líderes en detrimento de las propias formaciones políticas.

En el análisis cualitativo del estudio se ha abordado tanto el contenido del discurso, valorando la positividad del mismo, como el tema y el lenguaje audiovisual. Para este último parámetro, en el estudio de las piezas informativas se aplicó el análisis, ya asentado, de la tripartición de los elementos narrativos audiovisuales, creado por Francisco Javier Gómez-Tarín (2016), basado en la estructura de análisis fílmico. Este tipo de análisis ha sido aplicado por otros autores en posteriores estudios de comunicación política incluyendo además el análisis de los elementos constructivos del relato (Rodríguez Serrano, García Catalán y Martín Nuñez, 2019; p. 6).

Para la realización del análisis cualitativo se han creado unas fichas de análisis basadas en los elementos narrativos de Gómez-Tarín y posteriormente de Rodríguez-Serrano, García-Catalán y Martín-Núñez estudiando la puesta en escena, la puesta en cuadro y la puesta en serie. A continuación, se muestra el diagrama de análisis cuantitativo y cualitativo realizado en las distintas piezas, clasificando previamente cada unidad de estudio entre los diferentes informativos y partidos políticos previamente a su análisis. Esta metodología de análisis ha sido aplicada en cada una de las 266 piezas estudiadas, teniendo en cada ficha de análisis de contenido constancia del canal, de la fecha de emisión, el orden de aparición, y los partidos a los que se hacía referencia dentro de la misma, la duración de la pieza y la duración del informativo completo. 


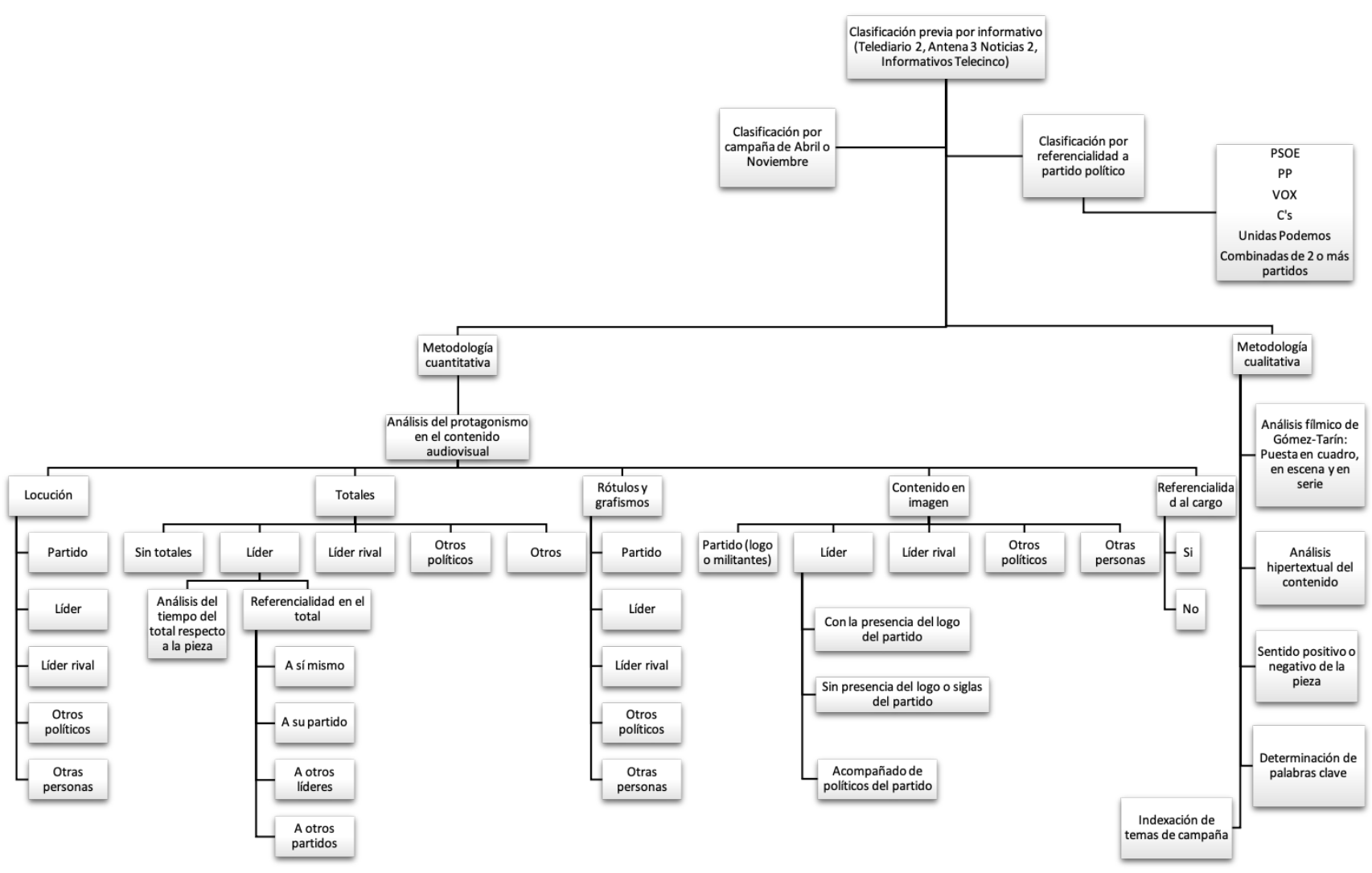

Gráfico 2. Diagrama metodológico de estudio de las unidades de análisis. Realización propia.

Este estudio es innovador porque existe una reducción del tiempo habitual destinado a las campañas electorales generales de 2019, debido a la repetición en un mismo año natural de las mismas. Este hecho sin precedentes ha llevado a que los principales informativos de televisión en España introduzcan cambios en el estilo y la forma en la manera que afrontan la cobertura mediática de estos procesos electorales para adaptarse a esta coyuntura. Sobre este escenario político y mediático se plantean las siguientes hipótesis:

H.1: Los informativos de televisión tienden a otorgar un mayor protagonismo a los líderes de los partidos políticos que a los partidos que representan.

H.2: La reducción del tiempo en campaña electoral es proporcionalmente inversa al protagonismo y presencia de los líderes en las piezas informativas.

H.3: TVE es la cadena cuya referencialidad explícita al cargo del líder político es residual a diferencia de las dos cadenas privadas.

\section{Análisis de los resultados}

\subsection{Protagonismo del contenido informativo en imagen, locución y rótulos en las piezas informativas}

En relación al protagonismo en imagen, locución y rótulos por partido y líderes según la campaña y los informativos (Gráfico 3), el análisis muestra que existen diferencias entre los noticiarios de las tres cadenas durante las dos campañas electorales. Los medios televisivos priman la figura del líder dejando en segundo plano la importancia de los partidos políticos, tal y como afirman Navarro y Olmo (2018: 1475). 


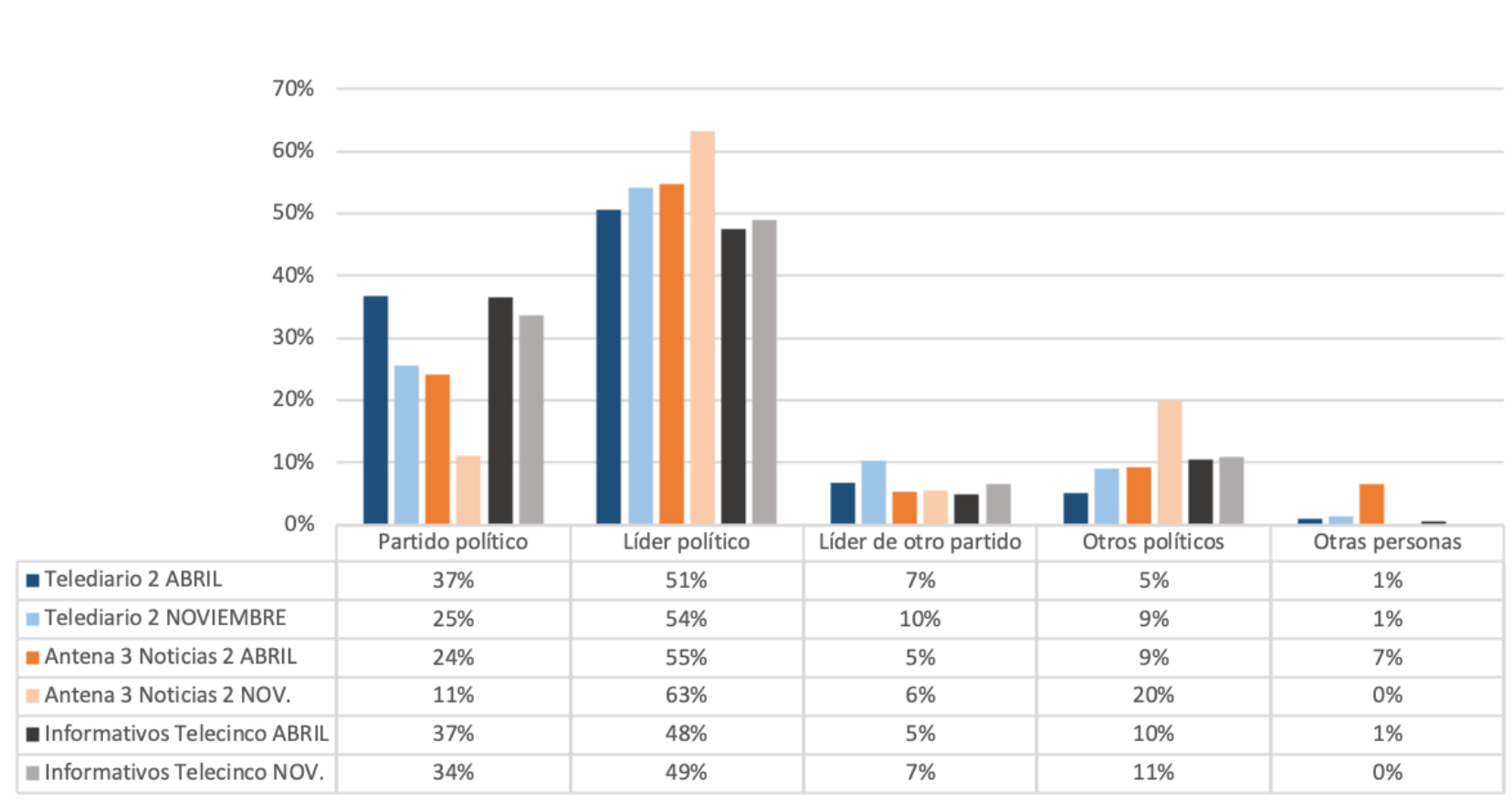

Gráfico 3. Protagonismo del contenido informativo en imagen, locución y rótulos en las piezas informativas. Realización propia.

El protagonismo en las imágenes, rótulos o locución haciendo mención sólo, o en una amplia diferencia, al líder político por encima de las referencias que reciben el propio partido en el que milita, ya sea de forma visual, sonora o texto, indica la personalización de las piezas políticas en los informativos estudiados. Los resultados del análisis llevado a cabo para las elecciones de abril, Antena 3 es la cadena que más protagonismo concede al líder político, obteniendo un $55 \%$ en más de la mitad de las piezas totales dedicadas al contenido político. Seguido por el Telediario de TVE cuya referencia al líder alcanza el 51\%, en detrimento de las referencias al propio partido. Los informativos de Telecinco otorgan protagonismo a los líderes en casi la mitad de las piezas, posicionándose en último lugar. De los datos obtenidos podemos concluir que, durante la campaña de abril, las tres cadenas analizadas destinan mayor protagonismo al liderazgo en su contenido de carácter político tanto en imagen como en locución y rótulos.

Como se puede apreciar en la gráfica, los datos obtenidos para los informativos de TVE y Telecinco muestran un promedio idéntico (37\%) en cuanto a las apariciones protagonizadas por el partido político durante la campaña de abril a diferencia de Antena 3 Noticias, donde el ritmo de apariciones del partido político es inferior a los otros dos informativos. De acuerdo a los resultados obtenidos, el protagonismo del contenido informativo en imagen, locución y rótulos dedicado a los líderes de otros partidos, otros políticos u otras personas es muy reducido.

En cuanto a la campaña para las elecciones del $10 \mathrm{~N}$ se puede observar un incremento de la importancia de los líderes políticos en los tres informativos. Antena 3 Noticias aumenta notablemente su porcentaje en un $8 \%$ en noviembre respecto a abril, alcanzando un 63\%. TVE y Telecinco recurren a esta misma estrategia, incrementando sus referencias al líder en perjuicio de las apariciones en imagen, locución y rótulo destinadas al partido político, obteniendo un $54 \%$ y $49 \%$, respectivamente.

Telecinco mantiene un porcentaje similar al producido durante la anterior campaña (34\%) respecto al protagonismo conferido a los partidos políticos. Por su parte, TVE reduce de forma considerable su porcentaje hasta un $25 \%$. Por otro lado, en las piezas 
de Antena 3 apenas se aprecia interés en materia de partidos políticos, obteniendo un escaso $11 \%$ de apariciones, redireccionando su atención hacia otros políticos.

Durante la campaña de noviembre existe una mayor inclinación hacia el liderazgo por parte del contenido informativo, frente a la campaña de abril. Parte de la atención que durante la campaña de abril se dedica a los partidos políticos, ha sido derivada hacia los líderes durante la campaña de noviembre, por lo que existe una tendencia evidente a la personalización política cuando las campañas se acortan. También se puede afirmar que la importancia de la categoría líderes de otro partido, como la de otros políticos en la campaña de noviembre es mayor. Cabe indicar que Pedro Sánchez es el líder que más presencia adquiere en las piezas del resto de partidos políticos al ser el PSOE la fuerza política más votada durante las elecciones precedentes y ser por tanto el partido de referencia a batir y a desgastar.

Las claves del protagonismo del líder respecto al partido político aparecen de forma manifiesta a través de la construcción del relato en una jerarquización donde prima el factor imagen sobre otros ítems al tratarse de la televisión. La imagen construida con los planos que se incluyen de los líderes supera a los planos donde aparecen logos o slogans de las fuerzas políticas a las que representan. A los datos cuantitativos de presencialidad en imagen de los líderes añadimos el estudio cualitativo en relación a puesta en escena, ya que el protagonismo de las piezas informativas recae en los candidatos. Por contra, las ambientaciones y localizaciones son secundarias, sobre todo en la campaña de noviembre, donde son menos habituales y visuales los escenarios ad hoc con los logos de los partidos.

Cabe destacar que, en la puesta en cuadro, los planos tienden a ser más cortos en la figura de los líderes, especialmente en la campaña de otoño. Por último, en la puesta en serie predomina la edición de piezas combinadas en ambas campañas y centra el montaje de cortes más en los líderes de forma visual que en los partidos. En ese sentido, en la edición de planos después de incluir en la secuencia a un candidato, incorporan a otro en el siguiente plano, lo que supone una concatenación de líderes en la noticia.

En el factor imagen se incluye también la rotulación o texto gráfico que acompaña a la imagen. En último lugar cabe señalar por jerarquía la voz en off del periodista que cita a los líderes políticos o a los partidos políticos. La voz en televisión es secundaria a la imagen, "una imagen vale más que 1000 palabras", una frase que la historia atribuye al dramaturgo y poeta noruego Henrik Ibsen. De esta forma, a través de la imagen, la rotulación y la voz en off, los tres informativos analizados personalizan la campaña de forma manifiesta, marcando un mayor protagonismo al líder o candidato en la campaña de noviembre.

Si separamos el protagonismo de los líderes políticos respecto a los partidos en materia de rotulación de las piezas, al margen de la locución y la imagen, cabe señalar que Antena 3 y Telecinco destacan sobremanera (56\% y 53\%) respecto al uso que hizo TVE (47\%) del total de las piezas. Es decir, las dos cadenas privadas otorgan mayor protagonismo en materia de refuerzo de liderazgo en las noticias con la utilización de la rotulación. Esta cuestión no es menor porque la utilización de la sobreimpresión en las noticias de carácter político otorga un plus de información a nivel sintético de resumen o traslación de las ideas fuerza que el periodista y la cadena otorgan a la información política. 


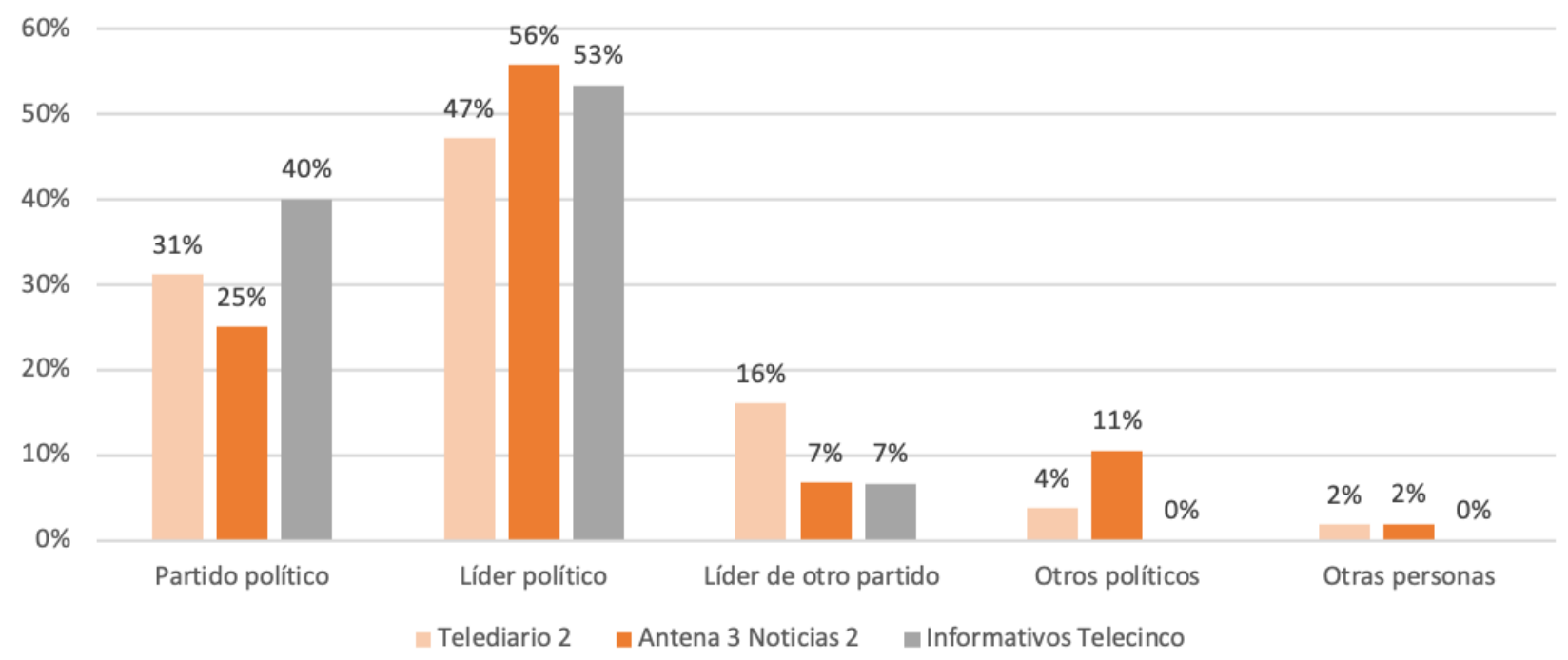

Gráfico 4. Protagonismo del contenido informativo en los rótulos en las piezas informativas.

Realización propia.

Obviamente la elección de un rótulo, como la propia redacción de la noticia o la utilización concreta de unas imágenes para editar las noticias, forma parte del criterio personal del periodista que va acorde con la línea editorial del medio al que representa, reforzando el factor de subjetividad inherente a la propia elección de un mensaje u otro en esa sobreimpresión.

Según el Gráfico 4, la diferencia del tratamiento de las 3 cadenas reforzando el liderazgo de los cabezas de lista respecto a los partidos políticos es muy notable. Antena 3 (56\% y $25 \%=31 \%)$, Telecinco (53\% y $40 \%=13 \%)$ y TVE $(47 \%$ y $31 \%=16 \%)$. El informativo de Antena 3 indica una mayor diferencia cuantitativa en porcentaje respecto a los otros dos con un 31\%, es decir, Antena 3 es la cadena que mayor protagonismo otorga a los líderes respecto a los partidos políticos en materia de rotulación, por tanto, de refuerzo visual escrito en sus noticias políticas en los dos procesos electorales.

Además, como hemos comentado en la introducción, TVE solo utiliza rotulación fuera de totales cuando es directo o falso directo del periodista mientras que tanto Telecinco como Antena 3 sí la utilizan. En el caso de las cadenas privadas están incluidas en las piezas por norma general con especial utilización en las piezas combinadas mientras que en el caso de TVE se trata del uso de rótulos sobreimpresionados en imágenes que tapan al periodista en directo o en falso directo cuando ofrece la crónica de la jornada o cuando convergen las imágenes de los líderes y los mítines bajo un formato de doble ventana.

En este caso aparece en la pantalla a la izquierda el periodista hablando y a la derecha se proyectan las imágenes. Son unas piezas donde sí hay rotulación por parte de la cadena pública. La utilización o no de rotulación en las piezas informativas en las cadenas de televisión obedece a criterios del libro de estilo de cada empresa. Por lo que respecta a TVE se trata además a un criterio de ser televisión pública con carácter más oficialista y bajo parámetros más asépticos que las cadenas privadas.

\subsection{Porcentaje del tiempo dedicado a los líderes en las piezas informativas}

El tiempo total de las piezas estudiadas es de 278 minutos y dos segundos de análisis audiovisual. Del total de las piezas estudiadas, un $23 \%$ corresponde a los cortes de 
voz de los líderes políticos y el 77\% restante a tiempo de noticia sin declaraciones por parte de los líderes. El tiempo que se destina durante las campañas electorales al líder político en los informativos de televisión es un aspecto muy importante, ya que sirve para formar su imagen en la opinión pública.

El primer elemento que marca la diferencia entre las dos campañas es el tiempo asignado a los cortes de voz del líder respecto al tiempo total de la noticia por campañas e informativos (Gráfico 5).

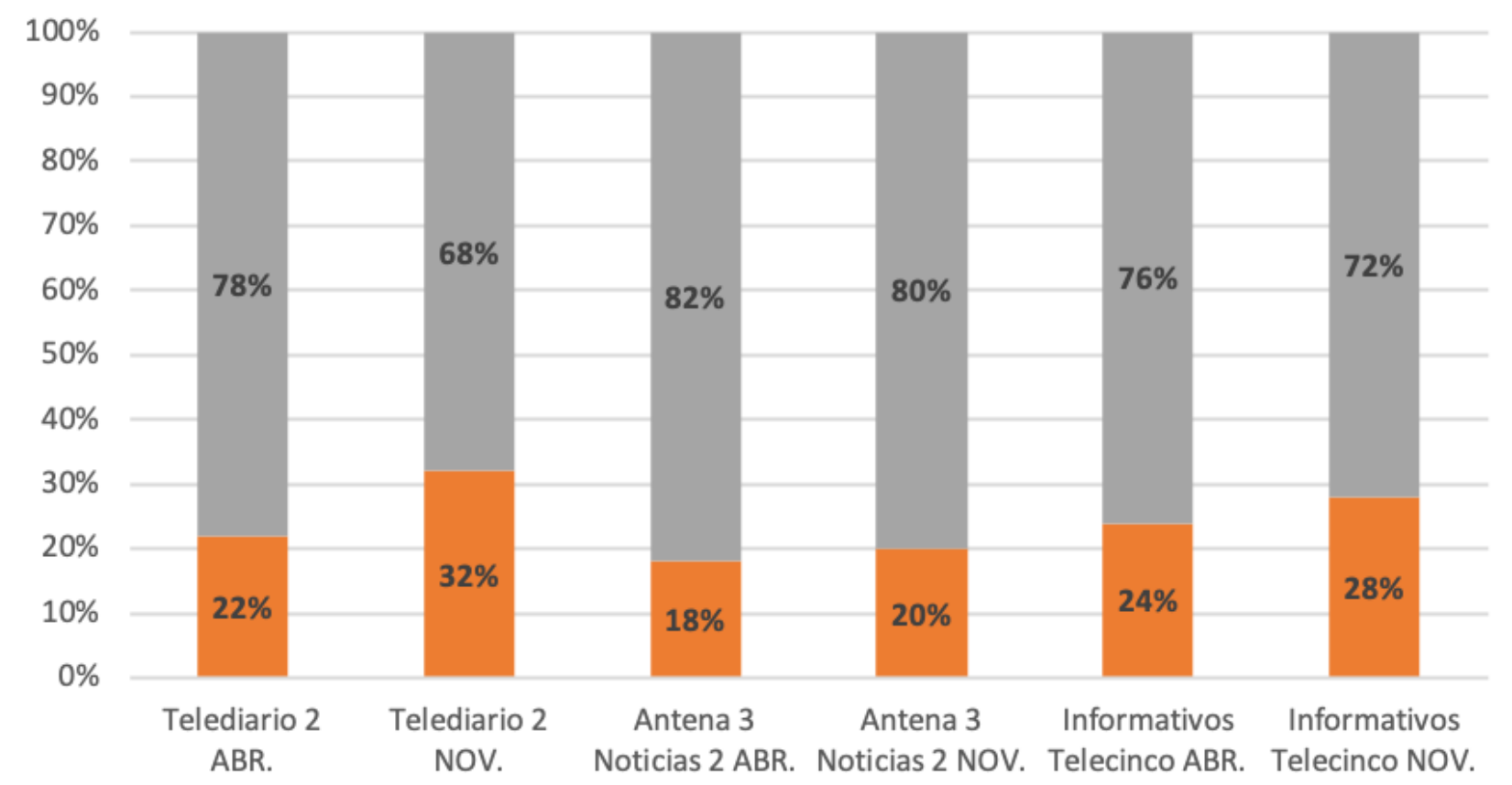

Gráfico 5. Porcentaje del tiempo dedicado a los totales (cortes de voz) de los líderes respecto al tiempo total de la noticia. Realización propia.

Según los datos reflejados en el Gráfico 5, los informativos de Telecinco alcanzan un $24 \%$ de tiempo medio dedicado a los totales de los líderes políticos (correspondiente a los cortes de voz) durante la campaña para las elecciones del 28 de abril, seguido por el Telediario 2 de TVE con un $22 \%$ respecto al total del contenido político. Desde un punto de vista cuantitativo, Antena 3 Noticias se sitúa en torno al 18\%, posicionándose en último lugar con respecto al resto de informativos analizados. Este último dato revela que la mayoría de las referencias al líder político, en el caso del informativo de Atresmedia, están realizadas a través de los rótulos, locución e imagen, no en totales.

Es importante destacar un aumento porcentual en el tiempo dedicado a los totales de los líderes políticos respecto al tiempo total de la información política durante las elecciones del $10 \mathrm{~N}$ (periodo de campaña electoral más corto de la historia, con solo 8 días) por parte de los tres medios analizados.

El Telediario de TVE remonta hasta el primer lugar con una subida del 10\% lo que supone un porcentaje total igual al $32 \%$, siendo la cadena que ha experimentado una mayor variación en sus resultados, seguido por los Informativos de Telecinco con un $28 \%$ del total de las noticias. Por otro lado, Antena 3 aumenta solo un $2 \%$ manteniendo unos porcentajes muy similares en ambas campañas.

Una vez analizados los resultados de ambas campañas, concluimos que el tratamien- 
to que los informativos otorgan a los cortes de voz de los líderes políticos se traduce en un aumento porcentual del protagonismo de los mismos durante la campaña para las elecciones del $10 \mathrm{~N}$.

En este contexto, resulta interesante analizar el tiempo de pantalla dedicado a cada uno de los líderes en relación con el total del contenido político de cada informativo y campaña. (Gráfico 6).

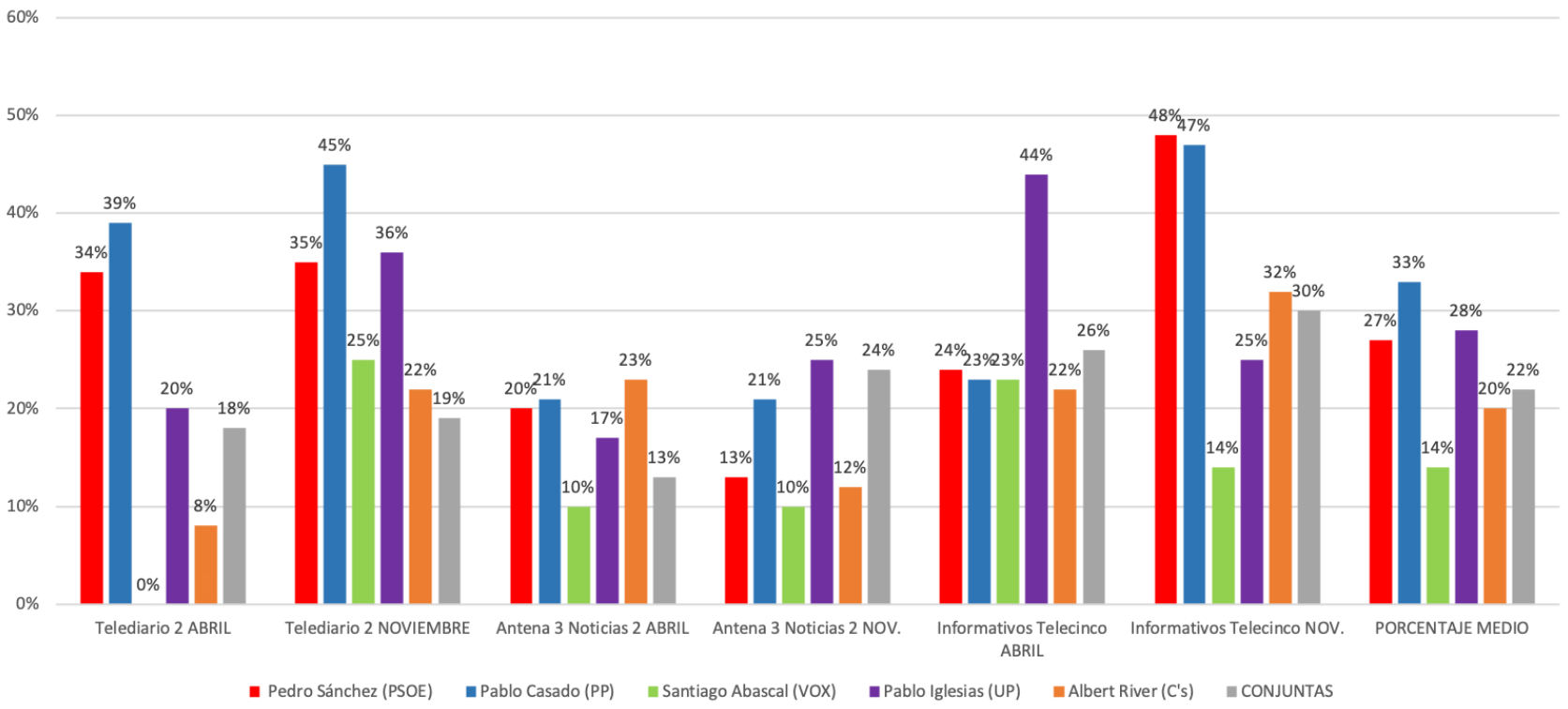

Gráfico 6. Porcentaje del tiempo dedicado a los líderes en las piezas por informativo y campaña. Realización propia.

Los resultados obtenidos en el Gráfico 6 evidencian claras diferencias porcentuales entre las dos campañas en cuanto al tiempo en pantalla dedicado a cada líder político, revelando una mayor inclinación hacia la figura del líder durante la campaña de noviembre.

Si comparamos la evolución en cada uno de los informativos, constatamos que en el Telediario de TVE se produce un aumento considerable del porcentaje de todos los candidatos, a excepción del líder del PSOE, Pedro Sánchez, quien ocupa en ambos procesos electorales el cargo de presidente del Gobierno en funciones. El auge de la derecha, representado por el partido Vox liderado por el candidato Santiago Abascal (que se convertiría en la tercera fuerza política en las últimas elecciones), obtiene el mayor ascenso, pasando de un $0 \%$ en la campaña de abril, a un $25 \%$ en la campaña de noviembre, ya que en esta última campaña ya contaba con representación parlamentaria adquirida tras las elecciones de abril.

Si centramos nuestra atención en Informativos Telecinco, podemos contemplar que, tanto Pedro Sánchez como Pablo Casado, duplican su tiempo en pantalla pasando de un $24 \%$ y un $23 \%$ en abril, a un $48 \%$ y $47 \%$ en noviembre, respectivamente. Por el contrario, los candidatos de las formaciones de Unidas Podemos y Vox experimentan una tendencia inversa en cuanto a su aparición en pantalla, bajando de un $44 \%$ a un $25 \%$ y de un $23 \%$ a un $14 \%$, respectivamente. El informativo que menos fluctuaciones presenta entre los dos procesos electorales es el de Antena 3 Noticias, dado que los tiempos que dedican a los totales en sus piezas son menores que en el resto de informativos, y también se ve afectado al mayor aumento porcentual de las noticias conjuntas. Es reseñable también que en la campaña de noviembre el porcentaje de tiempo dedicado 
a los totales de los líderes de los tres partidos con menor representación ( $C^{\prime}$, Vox y Unidas Podemos) aumentan en todos los informativos; esta tendencia puede ser debida a la polarización de ejes izquierda y derecha, y a la hipérbole de mensajes electorales en una campaña más reducida por parte de los candidatos de estas formaciones en la campaña de noviembre.

En este apartado cabe destacar también los resultados de la puesta en escena, en cuadro y en serie, donde claramente en la tripartición de los elementos narrativos (GómezTarín, 2016) se observa un protagonismo evidente en los planos que son seleccionados tanto en el montaje como en la escala de los mismos, abundando los planos más cortos en los líderes. En cambio, son inexistentes estos mismos para otros políticos que no son los candidatos. Cabe añadir también la falta de planos detalle de los logotipos de los partidos.

Por otra parte, las piezas que abarcan a varios políticos presentan mayor protagonismo en la campaña de noviembre.

\subsection{Referencialidad explícita al cargo del líder político en la pieza textual/ gráfico o locución en las tres cadenas seleccionadas}

Los datos que ofrece el Gráfico 7 son concluyentes respecto a los porcentajes que las cadenas han tenido en cuanto a la referencialidad concreta y directa al cargo de líder político en los bloques electorales de sus respectivos informativos. El análisis realizado en materia de off del periodista o rotulación (información gráfica) da resultados muy significativos. Las dos cadenas privadas muestran tanto en la redacción de sus crónicas, de los directos o falsos directos de los periodistas y de la rotulación que acompaña a las noticias, el cargo explícito de líderes políticos en la información de los dos procesos electorales de abril y noviembre.

$$
\text { - Sí No }
$$

INFORMATIVOS TELECINCO

ANTENA 3 NOTICIAS 2

TELEDIARIO 2

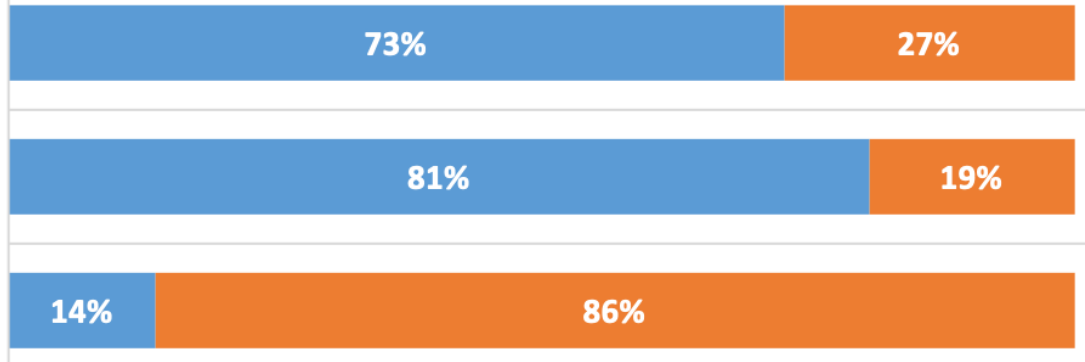

$14 \%$

\section{$86 \%$}

Gráfico 7. Referencialidad explícita al cargo del líder político en la pieza textual/gráfico o locución en las tres cadenas seleccionadas. Realización propia.

Antena 3, como hemos comprobado en otros ítems de esta investigación, es nuevamente quien contribuye a hacer sobresalir el liderazgo de los candidatos. En este apartado concreto, en un $81 \%$ de todas sus noticias ha hecho mención expresa a esta condición de número 1 o cabeza de lista de los representantes políticos. Unos datos que cumplen con la Hipótesis 3 y refuerzan claramente la Hipótesis 1.

En un porcentaje similar se encuentra el informativo de Telecinco con una referencialidad al líder de un $73 \%$ en todas sus piezas. En ambos casos, las cadenas privadas optan por una línea editorial clara de vincular la información de carácter político al candidato que 
lo representa en una visión de personalización de la información política, del estilo hiperpersonalista (Laguna, 2003), al que nos hemos referido en la Introducción.

Los resultados de Antena 3 y Telecinco contrastan claramente con el análisis realizado en las 107 piezas de TVE en los dos comicios. Mientras las dos primeras cadenas citan expresamente o gráficamente el cargo de líder de los candidatos en un $81 \%$ (Antena 3) y $73 \%$ (Telecinco), TVE solo hace mención expresa en el 14\% de sus noticias. Existe por tanto en el caso de la televisión pública una intencionalidad de evitar la personalización de la información política sobre el líder mientras que en las cadenas privadas buscan precisamente lo contrario.

Cabe señalar que en dos de las piezas analizadas de RTVE donde hay mención al líder se refieren a Pedro Sánchez como presidente del gobierno en un claro error por parte de la cadena al no obviar el cargo político que ostenta en funciones, ya que en campaña electoral todos los líderes han de ser tratados como candidatos y no en relación al cargo que tiene en el Ejecutivo.

\section{Conclusiones y discusión de los resultados}

La repetición electoral del año 2019, junto al escenario inédito de la reducción de los tiempos en campaña nos lleva a afirmar que se constata un incremento del protagonismo en imagen, locución y rótulos de los líderes frente a los partidos políticos. Es importante destacar que en ambas campañas la presencia de los partidos políticos en los informativos es inferior a la importancia otorgada al liderazgo, siendo mayor la diferencia en las elecciones de noviembre, por lo que a menor duración de campaña se produce un mayor interés informativo en personalizar las piezas políticas en sus líderes.

Existe un fuerte protagonismo de los líderes de los grupos políticos sobre sus propios partidos, teniendo en cuenta que el medio televisivo es visual y la imagen de los candidatos tiene una mayor relevancia en la construcción del discurso informativo en las elecciones (Hipótesis 1). La conclusión de esta hipótesis se ve reforzada no sólo por los datos cuantitativos de presencialidad en imagen de los líderes, sino del estudio cualitativo en el análisis de la puesta en escena, ya que como hemos visto el mayor protagonismo de las piezas informativas recae en los candidatos, lo que refuerza la teoría de autores como Donofrio (2019) o Rebolledo (2017) sobre la preponderancia de la imagen sobre el contenido y de la audiovisualización de la comunicación política.

Respecto al recurso de la rotulación para referirse a los líderes en las piezas como complemento a las ideas fuerza marcadas en la voz en off del periodista y la utilización de las imágenes, el trabajo demuestra que es utilizado más por las dos cadenas privadas y en menor medida por la televisión pública. El factor subjetividad de la utilización de un rótulo es evidente y TVE por su libro de estilo tiene un carácter más aséptico y menos de espectacularización de la información política.

La inestabilidad del mapa político tras las elecciones de abril de 2019 provocó las elecciones de noviembre, que tan solo tuvieron 8 días de campaña electoral. Ese acortamiento de los días de campaña en una semana ha producido resultados significativos en esta investigación porque demuestra que la reducción del tiempo en campaña electoral es proporcionalmente inversa al protagonismo y presencia de los líderes en las piezas informativas. En ese sentido, y dando más detalles de esta 
conclusión, los tres canales generalistas líderes de audiencia, Antena 3, TVE y Telecinco en los informativos estudiados, han aumentado el tiempo en pantalla dedicado a cada líder político, revelando una mayor inclinación hacia la figura del líder durante la campaña de noviembre (Hipótesis 2).

Con la demostración de las hipótesis se remarca la tendencia por parte de la televisión de sintetizar la campaña en la figura del líder, y aún más cuando ésta es más corta. El análisis de las piezas informativas demuestra que las tres cadenas de televisión contribuyen a la simplificación de la política con la construcción del relato informativo mayoritariamente a través de los candidatos (imagen, rótulos, cortes de voz, voz en off, directos...). De esta forma, el medio televisión articula el mayor protagonismo informativo hacia el candidato.

Bajo esta realidad, los telespectadores conocen la oferta política de la campaña a través de los líderes; lo que ellos dicen de ellos mismos, de su partido y de los otros líderes y fuerzas políticas es lo que el telespectador percibe en una clara tendencia de reducción de la política a la figura del candidato por parte de las cadenas. Las televisiones buscan el espectáculo y ayudan con la personalización de la política a la mediatización de la comunicación política, con las consecuencias que ello conlleva, ya que hoy para muchos autores la televisión sigue siendo el medio más decisivo para la elección de los votantes.

Para finalizar, otra de las conclusiones más evidentes es la referencialidad expresa del cargo del líder en las piezas analizadas. La investigación pone de manifiesto que Antena 3 y Tele 5 optan claramente por vincular la información en campaña electoral al candidato que representa al partido, en una intención clara de personalización de la política. Por el contrario, en TVE es residual el porcentaje de menciones concretas al cargo del líder, ya sea en la voz en off, en las intervenciones de los periodistas en sus crónicas en directo o en el grafismo que acompañan a las noticias (Hipótesis 3). Estos resultados muestran dos formas antagónicas de tratamiento del liderazgo en estas dos campañas electorales por el carácter público y privado de las cadenas.

Para investigaciones futuras proponemos que se avance en el análisis del protagonismo establecido por los programas informativos de las cadenas de televisión con la distinción entre líderes y partidos políticos. En ese sentido sería interesante establecer una comparativa con otras campañas electorales en España o en otros países para ver las similitudes y diferencias que tienen respecto a los resultados que hemos obtenido.

Respecto a la referencialidad al cargo de líder político en televisión, proponemos profundizar en esta tendencia incorporando datos combinados de análisis en la línea concreta del protagonismo en imagen a través de los cortes de voz de los candidatos. Ello nos permitirá ofrecer una visión más integral sobre el liderazgo político en las piezas televisivas de las elecciones generales de 2019 y en otros procesos electorales.

\section{REFERENCIAS}

Barlovento Comunicación (2016): Análisis televisivo anual 2015. Disponible en: https:// www.barloventocomunicacion.es/wp-content/uploads/2018/12/analisis-televisivo2015-Barlovento.pdf [Consulta: 5 de Noviembre de 2020].

Barlovento Comunicación (2017): Análisis televisivo año 2016. Disponible en: https:// www.barloventocomunicacion.es/wp-content/uploads/2017/01/analisis-televisivo- 
2016-Barlovento.pdf [Consulta: 5 de Noviembre de 2020].

Barlovento Comunicación (2019): Análisis televisivo anual 2018. Disponible en: $h$ ttps:// www.barloventocomunicacion.es/wp-content/uploads/2018/12/analisis-televisivo2018-BarloventoComunicacion.pdf [Consulta: 5 de Noviembre de 2020].

Banducci S., Cioroianu I., Coan T., Katz G., Stevens D. (2018): "Intermedia agenda setting in personalized campaigns: How news media influence the importance of leaders", en Electoral Studies, vol. 54, August, pp. 281-288. DOI:https://doi.org/10.1016/j. electstud.2018.04.011.

Berrocal, S. (2003): La personalización de la política. Comunicación Política en televisión y nuevos medios. Barcelona: Ariel.

Brants, K., Voltmer, K. (2011): "Introduction: Mediatisation and de-centralization of political communication", en Brants, K. y Voltmer, K. (Eds.), Political communication in postmodern democracy, pp. 1-16, Oxford: Palgrave Macmillan.

Bucy, E. P. y Grabe, M. E. (2007): "Taking television seriously: A sound and image bite analysis of presidential campaign coverage", en Journal of Communication, 57 (4), pp. 652-675.

Cayrol, R. (1997): “La televisión y las elecciones”, en Moragas, Miquel de (Ed.): Sociología de la Comunicación de masas, Barcelona, Gustavo Gili, 1979.

Casero-Ripollés, A. (2018): "Research on political information and social media: Key points and challenges for the future", en El profesional de la información, vol. 27, $\mathrm{n}^{\circ}$ 5, pp. 964-974. DOI: https://doi.org/10.3145/epi.2018.sep.01.

Campos, E., Valera, L., López García, G. (2015): “Emisores políticos mediáticos y ciudadanos en Internet: hacia un nuevo marco comunicativo en la jornada de reflexión en España", en Historia, Ciências, Saúde: Manguinhos, n²22, pp.1621-1637. DOI: https://doi.org/10.1590/S0104-59702015000500005.

Campos-Domínguez, E., Vicente, M. (2017): “Polarización discursiva en cibermedios españoles: representación de partidos e identidades políticas en las elecciones generales de 2015". En: López, G.; Valera, L. (eds.) (2017) Pantallas electorales. El discurso de partidos, medios y ciudadanos en la campaña de 2015. Barcelona: UOC, 79-97.

Campos-Domínguez, E., Calvo, D. (2017): “La campaña electoral en Internet: planificación, repercusión y viralización en Twitter durante las elecciones españolas de 2015", en Comunicación y Sociedad, 29, pp. 93-116. DOI: https://doi.org/10.32870/cys. v0i29.6423.

Centro de Estudios Sociológicos (CIS) (2019): Estudio n 3269. Barómetro de diciembre 2019. Postelectorales elecciones generales 2019. Realizado entre noviembre y diciembre de 2019, publicado el 16 de enero de 2020. Disponible en: http://datos. cis.es/pdf/Es3269marMT_A.pdf . [Consulta: 5 de Noviembre de 2020].

Colombo, F. (1976): Televisión: La realidad como espectáculo. Barcelona: Gustavo Gili.

Chadwick, A. (2017): The hybrid media system: Politics and power. New York: Oxford 
University Press. 2ª ed. ISBN: 9780190696733.

Crespo, I. (2002): Las campañas electorales y sus efectos en la decisión del voto Vol.1 Métodos y técnicas para el estudio de las campañas electorales, en Tirant Lo Blanch. Disponible en Internet: https://core.ac.uk/reader/229426700 [Consulta: 5 de Noviembre de 2020].

De la Paz Vila Márquez, F. (2016): El liderazgo mediado: Aznar y las estrategias de personificación de la política en las campañas de 1996 y 2000. Tesis doctoral. Universidad Complutense, Facultad de Ciencias de la Información, Departamento de Historia de la Comunicación Social. Madrid, 2016.

Del Rey, J. (1989): La comunicación política. Madrid: Eudema.

Donofrio, A., Rubio Moraga, A. L. (2019): “De Berlusconi a Trump: la comunicación convertida en espectáculo", en Estudios sobre el Mensaje Periodístico 25 (1), pp. 113127.

Enli, G. (2015): Mediated authenticity. How the media constructs reality. New York: Peter Lang. ISBN: 9781433114854.

Garzia, D. (2014): Personalization of politics and electoral change. Basingstoke: Palgrave Macmillan.

Gómez-Tarín, F. (2016): Elementos de narrativa audiovisual: expresión y narración. Shangrila, Cantabria, 2016.

Harris, L., Rae, A. (2011): "Building a personal brand through social net- working", en Journal of Business Strategy, n 32 (5), pp. 14-21.

Holtz-Bacha, C., Langer, A. I. y Merkle, S. (2014): "The personalization of politics in comparative perspective: Campaign coverage in Germany and the United Kingdom", en European Journal of Communication, 29 (2), pp. 153-170.

Keeter, S. (1987): "The illusion of intimacy: television and the role of candidate personal qualities in voter choice", en Public Opinion Quarterly, 51, pp. 344-358.

Laguna, A. (2003): “El poder de la imagen y la imagen del poder: la trascendencia de la prensa satírica en la comunicación social", en Revista Científica de Información y Comunicación, vol. 1, pp. 111-129.

Laguna, A. (2011): "Liderazgo y Comunicación: La Personalización de la Política", en Anàlisi 43, pp. 45-57.

Langer, A. I. (2011): The personalisation of politics in the UK: Mediated leadership from Attlee to Cameron. Manchester: Manchester University Press.

Lagares, N., Maneiro, E., González, S. (2020): “Consumo de medios de comunicación y redes sociales: Perfil de los votantes en las elecciones generales de España de Noviembre de 2019". en RISTI - Revista Iberica de Sistemas e Tecnologias de Informacao, $n^{\circ}$ E35 (09), pp. 546-558.

López García, G. (2016): "New' vs 'old' leaderships: the campaign of Spanish general elections 2015 on Twitter", en Communication \& Society, vol.29, nº 3, pp.149-168. 
DOI: https://doi.org/10.15581/003.29.3.149-168.

López-Meri, A., Marcos-García, S., Casero-Ripollés, A. (2017): “What do politicians do on

Twitter? Functions and communication strategies in the Spanish electoral campaing of 2016", en El profesional de la información, vol. 26, n 5, pp. 795-804. DOI: https:// doi.org/10.3145/epi.2017.sep.02.

López-Rico, C.M. \& Peris Blanes, A. (2017): “Los programas de entretenimiento: espectáculo y emoción en la comunicación política española". En López García, G. \& Valera Ordaz, L. (eds.): Pantallas electorales. El discurso de partidos, medios y ciudadanos en la campaña de 2015, Barcelona: UOC.

Manin, B. (1997): The principles of representative government, Cambridge: Cambridge University Press.

Martín Salgado, L. (2002): Marketing político. Arte y ciencia de la persuasión en democracia. Barcelona: Paidós.

Navarro, J.A. y Olmo, A. (2018): “Presencia política en Televisión Española en los últimos procesos electorales", en Estudios sobre el Mensaje Periodístico, 24 (2), pp. 1473-1488.

Pasquino, G. (2016): "La personalización de la política: más peligros que ventajas", en Cuadernos De Pensamiento Político, nº 50, pp. 19-24.

Pérez-Curiel, C., García-Gordillo, M. (2018): “Política de influencia y tendencia fake en Twitter. Efectos postelectorales (21D) en el marco del Procés en Cataluña", en El profesional de la información, vol. 27, n 5, pp. 1030-1040. DOI: https://doi. org/10.3145/epi.2018.sep.07.

Porath, W., León-porath, V., Ramdohr. T. y Suzuki, J. J. (2015): “Tres formas de personalización en la cobertura de la prensa chilena a las campañas presidenciales", en Trípodos, 37, pp. 9-28.

Rahat, G., Sheafer, T. (2007): “The personalization(s) of politics: Israel, 1949-2003”, en Political Communication, vol. 24, n 1, pp. 65-80.

Rebolledo, M., Rodríguez-Virgili, J. y Jandura, O. (2016): "Media coverage in times of crisis: a comparative study in different European contexts". En Ó. G. Luengo (Ed.): Political Communication in times of crisis, Berlín: Logos Verlag Berlin, pp. 101-119.

Rebolledo, M. (2017): “La personalización de la política: una propuesta de definición para su estudio sistemático", en Revista de Comunicación 16 (2), pp.147-176. https:// doi.org/10.26441/RC16.2-2017-A7.

Rodríguez Serrano, A., García Catalán, S., y Martín Núñez, M. (2019): “Estrategias narrativas audiovisuales de desinformación en YouTube de la nueva extrema derecha europea". El profesional de la información, vol. 28, n 3. DOI: https://doi. org/10.3145/epi.2019.may.11.

Rodríguez-Virgili, J., Jandura, O., Rebolledo, M. (2014): “La personalización de la política en la cobertura mediática: una comparación de las campañas electorales en España y Alemania", en Trípodos. n 34, pp. 61-79. 
Reinemann, C. y Wilke, J. (2007): "It's the debates, stupid! How the introduction of televised debates changed the portrayal of chancellor candidates in the German press, 1949-2005", en International Journal of Press/Politics, 12 (4), pp. 92-111.

Rico, G. (2009): Líderes políticos, opinión pública y comportamiento electoral en España. Madrid: CIS.

Rodríguez, J., Jandura, O., Rebolledo, M. (2014): “La personalización en la cobertura mediática: una comparación de las campañas electorales en España y Alemania" en Trípodos, 34, pp.61-80.

Rospir, J.I. (1999): “La globalización de las campañas electorales”. En: Muñoz- Alonso, A. y Rospir, J.I. (eds.). Democracia mediáticas y campañas electorales. Barcelona: Ariel.

Ruiz, F. J. y Bustos, J. (2017): "La evolución del debate televisivo como herramienta de comunicación política. Análisis del caso español: de la televisión a Twitter", en Información \& Sociedad: Est., Joâo Pessoa, 27(2), pp. 235- 252.

Sánchez-Murillo, L. F. (2005): “El marketing político y sus consecuencias para la democracia", en Comunicación y sociedad, n. 4, pp. 11-38.

Sanjuan-Perez, A., Martínez-Costa, S., Nozal-Cantarero, T. (2019): “Presencia de partidos y líderes políticos en las principales cadenas de televisión en abierto durante la campaña de las elecciones generales de 2019 en España", en Estudios sobre el Mensaje Periodístico, 26 (2), pp. 1195-1204.

Scammel, M. y Semetko, H. A. (2008): "Election news coverage in the U.K.". En: J. Strömbäck y L. L. Kaid (Eds.), The handbook of election news coverage round the world, Nueva York: Routledge, pp. 73-89.

Schulz, W., Zeh, R. y Quiring, O. (2005): "Voters in a changing media environment: a databased retrospective on consequences of media change in Germany", en European Journal of Communication, $\mathrm{n}^{\circ}$ 20, pp. 50-58.

Selva-Ruiz, D.; Caro-Castaño, L. (2017): “Uso de Instagram como medio de comunicación política por parte de los diputados españoles: la estrategia de humanización en la "vieja" y la "nueva" política", en El profesional de la información, vol. 26, n 5, pp. 903915. DOI: https://doi.org/10.3145/epi.2017.sep.12.

Van Aelst, P., Sheafer, T., Stanyer, J. (2012): "The personalization of mediated political communication: A review of concepts, operationalizations and key findings", en Journalism, 13 (2), pp. 203-220.

Villar-Hernández, P. (2020): "El discurso pseudopolítico de la segunda pantalla. \#EIDebateEnRTVE visto a través de sus prosumers", en Revista Latina de Comunicacion Social, 76, pp. 121-141. DOI: https://doi.org/10.4185/RLCS-2020-1440.

Wattenberg, M. (1998): The decline of American political parties, 1952-1996, Cambridge: Harvard University Press. 